\title{
Gender and management of crop diversity in The Gambia
}

\author{
Edwin Nuijten ${ }^{1}$ \\ Wageningen University, the Netherlands
}

\section{Introduction}

In traditional farming systems, crop diversity provides the opportunity for farmers to keep their options open. Diversity does not necessarily lead to yield increases, but it is linked to yield stability. Because women play a bigger role than men in many cropping systems, it is often asserted that they frequently control seed selection and management of crop varieties (Howard 2003). This would imply women have more knowledge of plant diversity and have an important role in the management and conservation of plant genetic resources. It is also stated that "[crop] domestication has often depended on the observational powers of women who historically have been most associated with seed selection and thus with noticing new varieties which spontaneously appear in the field" (Prain 1993). This would suggest that women 'naturally' are more interested in crop diversity than men are, as Vandana Shiva (1988) has argued.

To respond to the question of whether innate gender differences exist in seed selection and crop diversity management, and if so why, I make a comparison of how men and women in the same compounds actually manage two crops with different breeding systems. In The Gambia women are responsible for the cultivation of rice (a self-pollinating crop) and men for the cultivation of pearl millet (a cross-pollinating crop). The gendered management of crop diversity is analyzed, in order to understand the factors that best account for apparently better management of crop diversity by women. First, a historical overview of gender in farming in The Gambia is given, followed by a discussion of the gendered relations of crop diversity management of rice and millet. The last section describes the results of a grouping experiment of millet spikes and rice panicles done by both men and women.

Durkheim argued that masculine aspects of culture are related to power and that feminine aspects are related to compassion (Mestrovic 1992), while Shiva (1988) also argued for strongly gendered characteristics and attributes. An important question therefore is to try and resolve which characteristics might be typically masculine and typically feminine, and whether these are acquired ('nurture') or preexisting ('nature'). To do so is, however, is very difficult. One of the main problems is how to explain both the enormous observable variation in cultural understandings of what the categories 'man' and 'woman' mean, and yet how certain notions about gender appear in a wide range of different societies (Moore 1988). ${ }^{2}$

The idea that women are better in crop variety management and conservation seems to be supported by case studies of rice farming in Southwest Casamance (Linares 1981), of beans in Rwanda (Sperling et al. 1993), and of rice production in the Garhwal Himalaya region of India (Shiva and Dankelman 1992). Other case studies suggest that seed and variety management is regulated in variable and complex ways. Where maize is the prime crop in Mexico, it is both men and women who are involved in seed selection - men select superior plants in the field, while women select superior ears of corn during cooking (Rice et al. 1998). In Peru cassava is a women's crop, but the (male) shamans play a crucial role in cassava variety management and development (Salick et al. 1997). In central Sierra Leone men and women are both involved in rice variety management and development (Richards 1986) whereas in Northern Sierra Leone, it appears that often only men are involved in seed purification (Jusu 1999).

There are a range of reasons offered as to why women are traditionally more involved in crop variety management and conservation. Because women usually are responsible for processing and cooking, they need, and consequently conserve, a wide range of varieties and crop characteristics (Worede and Mekbib 1993). In certain areas women might need a greater set of varieties because they are farming under more marginal and diverse conditions than men. In Zimbabwe, fertiliser is predominantly used on men's crops, which are also cash crops, grown on the best fields, leaving women to grow subsistence crops on poorer soils without inputs (van Oosterhout 1996). Higher levels of diversity often occur under marginal cultivation conditions and are more related to subsistence crops than to cash crops (Nuijten 2005). In the case of maize in southwest China seed and variety management, together with farming in general, has shifted towards the women's domain because many men have gone to the urban areas to look for work (Song and Jiggins 2003). The same pattern is visible in Andean potato producing regions in Peru (Zimmerer 1991). Boserup argued that in African farming systems colonial capitalism frequently gave more responsibility for subsistence

\footnotetext{
${ }^{1}$ Dr. Edwin Nuijten, Technology and Agrarian Development Group, Wageningen University, Hollandseweg 1, 6706 KN Wageningen, the Netherlands. edwin.nuijten "at" wur.nl. An earlier version of this manuscript was presented at the AEGIS Conference, at SOAS, London in 2005. I thank Prof. Paul Richards and two anonymous reviewers whose comments have significantly improved the manuscript. The research was funded by NWO-WOTRO.

${ }^{2}$ In future, it may be possible to disentangle people's endowed and acquired characteristics, by looking at the impact of the various hormones regulating physical differences between men and women and emotional differences. But for now, it is difficult to identify strictly gendered characteristics. None of this would alter a true social (or political) fact that in many cultures, despite their differences, women have a secondary status in society (Boserup 1970).
} 
farming to women (1970). The expansion of capitalism actively created a new sexual division of labor (Guyer 1980).

After the introduction of a new commercial crop by men, for example, women can lose influence and power. But it might also be possible that over time they are also able to regain their lost influence and control until a new power dynamic is established (Haswell 1975). Some argue that any resulting conflicts of interest are rooted in the nature of social relationships themselves, and the social relations of production, rather than being 'natural' or inevitable (Whitehead 1984).

The literature illustrates that crop diversity management is influenced by a range of socio-cultural, economic, political and agro-ecological factors, but they do not refute the possibility that women have a general affinity for plants that exceeds that of their male counterparts (Howard 2003; Shiva and Dankelman 1992). Because of their limited access to new agricultural technologies, women may have developed certain skills in the management of cultivars in order to cope with the circumstances under which they farm. If research finds that women do not have more affinity for plants than men, it may be argued that their farming skills are an important indicator of a disadvantaged position in society. In large measure, the political ecology of agriculture in The Gambia supports this assertion. The case studies here explore the differential skills of men and women in the same communities, in order to test some aspects of this relationship.

\section{Methodology}

The research used an interdisciplinary approach, integrating biological and anthropological methods. ${ }^{3}$ From 2000 to early 2003 semi-structured and informal interviews were conducted with 77 farmers in the western part of The Gambia in four villages (Tujereng, Kitti, Faraba and Janack), where agro-ecological conditions are relatively similar. The reason I worked in the western part of the country was the limited number of agricultural interventions made there. The majority of the 77 farmers were interviewed several times during the research period. The four villages were studied in detail to achieve a better understanding of farmer management of seeds, crop varieties, and pollen flow. In all four villages short duration upland rice and late varieties of pearl millet were cultivated. The upland rice was cultivated in areas prepared for cultivation through slash and burning, or in the upper stretches of the lowlands that were usually free of swampy conditions. The villages were selected so they formed a line from west to east at intervals of 20 to $30 \mathrm{~km}$. The first three villages are Mandinka villages with large populations of Jola. Janack is a Jola village. In terms of farming practices there are no clear differences between Mandinka and Jola in the study area. In this region the Jola can be considered 'Mandinginised' (see Linares 1992).

In 2002 a questionnaire on management of crop and variety diversity was conducted with 135 compounds in 11 villages in four regions across the country (Kombo, Foni, Kiang, Fuladu) (Fig. 1). In each compound a man and one of his wives were interviewed separately about millet and rice production. The purpose was to understand how biological and socio-economic variables may vary over a larger region. Rainfall is highest in Kombo region, lowest in Kiang region with Fuladu and Foni regions in between. The agro-ecological conditions in Foni are relatively similar to those in Kombo for both rice and millet. Foni is a typical rural region whereas life in the rural areas in Kombo is strongly influenced by proximity to urban areas. Kiang and Fuladu are also typical rural regions. In the four regions different types of millet and rice were cultivated. In Kiang, farmers cultivated rice in associated mangrove swamps and early millet (suno) in the uplands. The late millet (majo) cultivated in Fuladu was a different type from the late millet (sanyo) cultivated in Kombo and Foni. In Fuladu agro-ecological conditions for rice were similar to those in Foni but the spatial area was more constrained by geography.

In 2003 a grouping experiment was conducted with 21 farmers from Tujereng and Faraba. Because rice is grown exclusively by women and millet by men, men often do not know the exact names of rice varieties and women don't know millet varieties. So, it was not possible to compare men's and women's knowledge of variety naming. Instead, men and women from Tujereng and Faraba (see Fig. 1) were asked to group inflorescences of millet and rice, millet spikes and rice panicles respectively, based on their morphological features. In total, 11 men and 11 women from Tujereng and 10 men and 10 women from Faraba were asked to group 35 millet spikes and 30 rice panicles from different varieties of late millet and upland rice.

\footnotetext{
3 The field trials and molecular analysis are described in Nuijten and Van Treuren (2007). For the integration of morphological data and interview data in relation to mechanisms explaining variety naming see Nuijten and Almekinders (2008).
} 


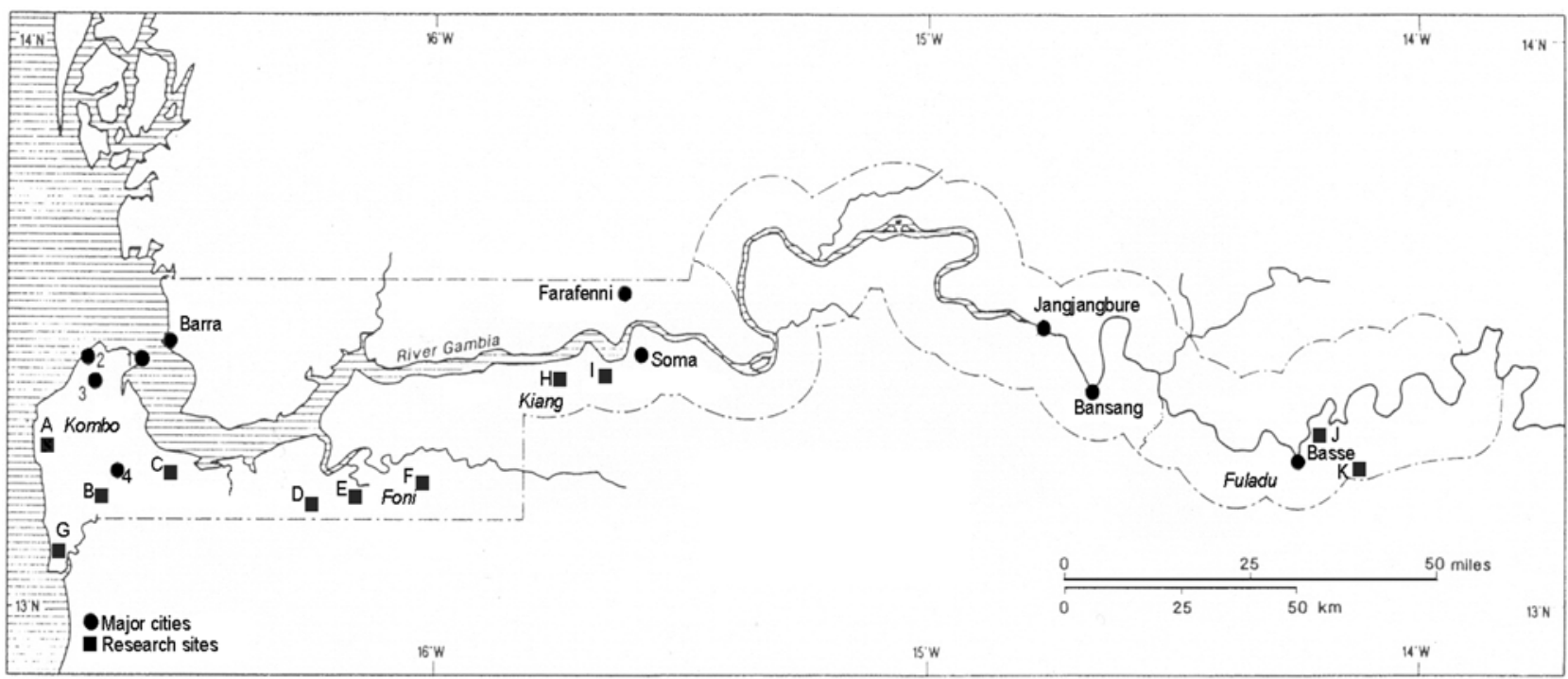

Fig. 1: Research sites: A: Tujereng, B: Kitti, C: Faraba, D: Janack, E: Batabut Kantore, F: Sangajor, G: Kartong, H: Jiroff, I: Massembe, J: Damfakunda and K: Sanending; Major cities: 1: Banjul (Capital), 2: Bakau, 3: Serrekunda and 4: Brikama.

\section{Change in Gambian farming system from 1800 to 2000}

The Gambia is one of West Africa's ecological, social, and cultural frontiers (Brooks 1993). It is a transition zone between savanna and forest habitats. South of The Gambia rice is the main staple food, whereas to the north and north-east, pearl millet and sorghum are the main staples, except in areas near rivers. According to Tosh (1980) agriculture in the savanna zone requires more and better organised labor, because of the shorter cultivation season and steeper labor peaks. Consequently, it is more common for farm operations to be shared between men and women: for example, men prepare the land, women sow and weed, and all take part in the harvest. In certain areas in Mali no gendered division in tasks exist at all (Toulmin 1992, Lewis 1981). But in the forest zone, for example further south in Sierra Leone, there is more gender segregation. It is easier for men to organise a large labor force than it is for women because they have more power (Johnny et al. 1981). Hence, they concentrate on upland farming where labor peaks can only be mitigated by large labor groups, while lowland rice farming and vegetable gardening, regions where women dominate, have a more of a constant labor requirement.

Labor organisation is not only regulated by practical agronomic factors, but also by economic and socio-cultural conditions (Guyer 1980). Guyer (1984) argues that the different working rhythms of men and women emerge from their institutionalised means for mobilising labor, and that the resulting differences in cropping systems are a reflection of social power, rather than the result of innate gender difference. This also helps explain the organisation of labor and crops in The Gambia. According to Webb (1992), the Mandinka rice farming system in The Gambia is gendered, although the term describes the prevailing ecology as much as it does the Mandinka ethnic group itself. Swamp rice cultivation is less common in the former Mandinka Wuli kingdom in Eastern Gambia, and yet the organisation of labor in farming there was gendered, which suggests its labor organisation has an ethnic origin. In Wuli men used to grow millet, sorghum, groundnuts and beans, and women grew findo (hungry rice), chickpeas, groundnuts and vegetables in the same fields (Weil 1984). In the few available depressions, women grew rice. ${ }^{4}$ According to Weil (1984), this gender divide reflects the labor requirements of the various crops: vegetables and rice require daily, or at least regular, care and are thus women's responsibility. However, groundnut, a male crop, also requires regular care. So, apart from labor requirements a second factor determining a gender-based labor division is whether a crop is meant for subsistence or for sale. It seems to be a general rule that men take the responsibility for the cash crops (i.e. groundnut), while women have the responsibility for the subsistence crops (Howard 2003). Whereas in The Gambia rice is a staple food grown by women, in Mali and Sierra Leone men are involved in rice cultivation in various degrees, depending on the importance of rice as a cash crop (see Johnny et al. 1981; Nyanteng et al. 1986; Richards 1986).

In addition, Guyer (1984) suggests that differences in labor organisation are also related to the longevity of individual crops: indigenous staples are characterised by complex and ritualised labor

\footnotetext{
4 In those Mandinka systems where it is not possible for women to cultivate rice that can be sold, they can sell the produce of other crops, such as groundnut, sorghum, beans or vegetables. The crop that women are allowed to sell differs between regions.
} 
organisations, ${ }^{5}$ whereas recently introduced staple crops tend to be individuated, gender-specific and secular in their management. The farming system in The Gambia is perhaps something of an exception, since rice, a traditional staple, is grown by women. But Guyer's argument is valid in the sense that "the introduction of a new crop in a farming system is a medium for, and expression of, the re-negotiation for the organisation of labor" (1984). Hence, cash crops, usually foreign in origin, tend to increase the overall gender-based division of labor (Boserup 1970). This happened with the commercialisation of groundnuts in The Gambia, which resulted in rice being pushed into the women's domain.

Before 1860, rice production was primarily the domain of women, but men had the responsibility for certain tasks, most notably the preparation of the land prior to transplanting the rice (Watts 1993). Only around 1860 did a transformation occur in Mandinka agriculture from task-specific to crop-specific gender roles (Carney 1993; Swindell 1992; Watts 1993). With the groundnut industry booming around 1830, Mandinka men began to monopolise groundnut production, and rice farming became entirely women's work. Furthermore, compared to swamp rice cultivation, groundnut is less subject to locust ravages and less labor intensive (Swindell 1980). Because of the high profits from groundnuts, male farmers concentrated more on them than on food crops (Watts, 1993; Swindell, 1992). Whereas before 1800, The Gambia was known as a food exporting country (Carney, 1989), it became a food importing country by 1830 during the groundnut boom. Rice changed from being an export crop to an import crop, and was grown locally for subsistence (Watts 1993).

For almost all (about 95\%) of the rural population, today's agricultural production is gendered. Some new patterns are visible. In those areas where rice cultivation is not possible anymore because of reduced rainfall, women cultivate their own millet and groundnut fields, separate from the men. In the irrigated rice areas, men also work in the rice fields (Carney 1993). To a large extent they have control over women's labor and over the income generated from the sale of rice paddy. As a result some women prefer to grow rice outside the irrigated areas where their husbands cannot exert control over them. Another divergent pattern is visible among the Manjago, who settled in The Gambia in the 1960s and 1970s from Guinea-Bissau. In Manjago culture, traditionally there is no gendered divide in crop cultivation and men and women cooperate in rice farming (like the Jola in southwest Casamance). But some second or third generation Manjago, born in The Gambia, are gradually adopting Mandinka culture.

\section{National and international efforts to improve food production}

Before World War II very few efforts were made to improve rice cultivation. The focus of British agricultural research was on groundnut and other crops that could be cultivated in upland areas (see The Annual Reports of the Department of Agriculture, 1925; 1926; 1931; 1932; 1934; 1936; 1939). In 1939 it was mentioned that men concentrated too much on groundnut cultivation for export, causing problems in years with low prices because they were unable to provide enough food for the family. But with the introduction of animal traction in the 1950s men increased the size of their groundnut fields even further, at the expense of food crop production (Weil, 1970).

In 1949 the first irrigation scheme was initiated by the colonial government at Jahally Pacharr, but only 200 acres was irrigated even though 10,000 acres was planned (Carney 1998). A lesser known but more successful initiative of the colonial government was the clearance of mangroves and the construction of causeways and footbridges in the central upstream part of the river basin in the early 1950s. This was meant to improve access to the deep-water swamps and the distribution of formal rice varieties, so that women were able to increase their rice production, which balanced the decrease in (millet) food production cultivated by men (Watts, 1993; Haswell, 1991). In these areas women were indeed able to increase their rice production, this was because they now had access to more fertile fields (compared to the less fertile upland fields). Women could sell surplus rice and were able to increase their financial independence (Weil, 1973). The surplus in rice was sold on the Banjul market, which reduced profit margins for rice-importing merchants. In 1954, under pressure from the merchants, the state prohibited the export of rice from the Protectorate and completely stopped its flow from the provinces (Watts, 1993). However, in the 1950s awareness also arose that the uncontrolled importation of cheap rice would run counter to the development of a strong domestic rice industry (Haswell, 1963). By the mid-1960s, then, increases in rice production increases in the mangrove swamp ecology halted because of growing labor shortages. Machinery did not substitute for manual labor, and its use in swampy fields may have anyway been problematic. Gambian women had other reason to avoid the use of mechanical ploughs and other equipment - they feared it would lead to men gaining more control over production (Baker 1995).

During the 1960s and 1970s the irrigation schemes near Jahally Pachar were enlarged, through funding from various donors, mainly the Chinese and Taiwanese governments and the World Bank. To reduce the dependency on rice imports, more than 4,000 ha of swamp was converted into irrigated rice fields suitable for double cropping (Carney, 1992). The irrigated rice fields are the only areas today where farmers can produce a certain surplus of rice for sale. But efforts by the government to significantly improve food self sufficiency through increased rice production have yet to be successful. This is partly because the population of the Gambia is still growing. The total area cultivated with rice has declined across all ecologies since the

\footnotetext{
${ }^{5}$ An example would be the traditional Jola rice farming system in South-west Casamance (Linares, 1992).
} 
early 1970s, in particular due to rainfall decline. Additionally, about half of the irrigated rice fields are unavailable for irrigation due to lack of resources (Marong et al., 2001). Further gains in food availability would only be possible by altering the gender division of labor, drawing men into rice growing (Carney, 1993; 1998). Although rice yields have increased, these are not sufficient to balance the decrease in cultivated area and rising demand for rice (Nuijten, 2005). The government also tried to increase millet and sorghum production but again failed. One reason is that male farmers find it unattractive to produce more food after having been engaged in a monetary economy for 150 years (Barrett, 1988).

After the droughts that affected much of the West African Sahel in the 1970s and ushered in international development aid, assistance to improve food production in The Gambia emphasised improved production of rice and vegetables (both traditionally grown by women) to be sold on the market (Carney, 1992). United Nations, World Bank and NGO officials believed cash cropping would benefit poor women and their children (Baker, 1995). But the commercialisation of rice (applicable only to the irrigated fields in the eastern part of the country) and vegetables has proceeded amid a welter of conflicting productivity and equity objectives (Carney, 1992; 1993; Schroeder, 1997). For example, there was no precedent for (male) household heads to invoke female labor obligations for two cropping seasons a year in the irrigation schemes (Carney 1992). ${ }^{6}$ To increase rice production in upland rice fields, NGOs promoted line sowing in order to speed up weeding and reduce weed competition. This practice was not adopted because men, who own the row seeders needed for line sowing, would not assist their wives with the task. As described in the next section, this was because male and female work units within the same compound largely work independently from each other (Nuijten, 2005).

The conclusion of all these development efforts is that that tended to reinforce gender divisions in production tasks and crop types. I will now assess the extent to which gendered crop management is accounted for by the social conditions of production, or whether innate gender differences in skill and aptitude are revealed.

\section{Crop diversity and gendered knowledge in The Gambia}

In this section I present data from semi-structured and informal interviews conducted in Kombo region over the period 2000 to 2003, and a questionnaire conducted across the country in 2002.

\section{On and off-farm income sources}

Compared to male farmers, female farmers in the study villages have fewer income sources than men, 2.1 and 1.5 respectively (Table 1$)$. Also fewer women (32\%) than men (49\%) have off-farm income sources. Table 1 does not give an indication about the relative importance of these income sources, but it shows that arable crops and fruit trees are the most common on-farm income sources for men and that vegetable gardening is the most common on-farm income source for women. Whereas men usually have orchards, women only have a few trees in their faro (a term for a lowland rice field that is not completely flooded) or garden, and their income from fruit trees is much more limited compared to that of men (Table 1). The high percentage of women in Fuladu in the east (see Fig. 1) having income from arable crops is because they cultivate groundnuts and sesame for sale.

The promotion of vegetable gardening by aid agencies as a substitute for rice farming from the 1970s provided an independent income source for women (Baker, 1995; Schroeder, 1997). In certain areas, where men's income depends largely on declining groundnut harvests and sales, women's income from gardening has become indispensable during the dry season (Schroeder, 1997). Traditionally, it is the man's responsibility to take care of all family expenses, like food, clothing, taxes, school fees, etc. But in practice women's income has become very important, in some cases indispensible, for household expenditures.

The differences in percentages of off-farm income sources between villages near the urban areas and those further away are very small for men (Table 1). For women, the differences are larger and show some irregularity: In Kiang 50\% of the women have other income sources, while the equivalent figure in Fuladu is only $5 \%$. To a large extent, vegetable gardening is related to the percentage of women with off-farm income sources. In Kiang, for example, not many women are involved in gardening because swamp rice is flooded with salt water during the dry season and, secondly, because the low groundwater table makes it very difficult to draw water by hand. An explanation for the rather low percentage of gardening activity in Foni may be the long distances from markets, in combination with the limited availability of rice swamps with high groundwater tables. A possible explanation for the low percentage for off-farm income sources in Fuladu is that many women in that district have other income from the sale of groundnuts and sesame.

\footnotetext{
${ }^{6}$ Because there is already extensive literature on the effects of international development efforts on irrigated swamp rice production, and the present article does not deal with this environment, the interested reader is referred to Judy Carney's work $(1992 ; 1993)$.
} 


\begin{tabular}{|c|c|c|c|c|c|c|c|c|c|}
\hline District & $\begin{array}{l}\text { Number } \\
\text { sources }\end{array}$ & ome & $\begin{array}{l}\text { Sale of } \\
\text { crops }\end{array}$ & & Sale & & $\begin{array}{l}\text { \% women } \\
\text { doing } \\
\text { gardening }\end{array}$ & $\begin{array}{l}\text { \% wit } \\
\text { incom }\end{array}$ & $\begin{array}{l}\text { arm } \\
\text { ces }\end{array}$ \\
\hline gender & $\pi$ & 우 & $\pi$ & q & $\hat{0}$ & q & & $\sigma^{\pi}$ & q \\
\hline Kombo & 2.3 & 1.6 & 93 & 11 & 82 & 44 & 90 & 53 & 31 \\
\hline Foni & 2.2 & 1.1 & 90 & 31 & 80 & 14 & 40 & 48 & 42 \\
\hline Kiang & 1.7 & 0.9 & 100 & 0 & 20 & 5 & 40 & 43 & 50 \\
\hline Fuladu & 2.0 & 2.1 & 85 & 85 & 65 & 40 & 80 & 43 & 5 \\
\hline total & 2.2 & 1.5 & 92 & 25 & 69 & 31 & 70 & 49 & 32 \\
\hline
\end{tabular}

Table 1: Number of income sources and percentages of men and women who have income from agriculture and off-farm sources in four villages. $\mathrm{N}=127$ for men and $\mathrm{N}=132$ for women.

1) = mostly during the dry season

\section{Farming resources}

One clear difference between men and women in terms of resources is the availability of labor. The average dabadaa (male labor force in a household) consists of $5.1 \mathrm{men}$, while the average sinkiroo (female labor force in a household) consists of 2.9 women. The number of women that work alone is greater than men. One explanation for this is that the numbers refer to men and women working in the millet and rice fields respectively. So, some women who only work within the compound and not in the rice fields, may be excluded from these figures. An additional explanation for the different sizes of the male and female labor force is that the average number of sinkiroo per compound (1.8) is somewhat higher than the average number of dabadaa per compound (1.5). In cases of illness or other misfortune in the household, women are more vulnerable than men. Since the female sinkiroo numbers are smaller than the male dabadaa, it is more common for women to call in the help of their kafo (working group organised by age and gender) (Nuijten, 2005). The adult women kafo also tends to remain active laborers to an older age than the male kafo. An advantage of kafo work is that the work is a communal activity and therefore less of drudgery. A disadvantage is that some members of each kafo group are less active participants than others, leading to tensions between the members. In that sense being able to marshal a big household labor force (like a dabadaa or sinkiroo), with a leader and defines tasks, could be preferable.

Traditionally land is owned by men, including the land cultivated by women with rice. In lowland faro plots, women have usufruct-rights to land, and these rights are passed on to the wives of their sons. Likewise daughters when married obtain usufruct-rights to the land of their mothers-in-law. Although there may be exceptions - nowadays land can be purchased by women - elsewhere in the country patrilineal inheritance is the norm. To secure access, women may obtain cultivation rights from other women, or lend to others in order to build up patron-client relationships (Kea, 2004). They may also cultivate across an ecological gradient where possible, on different plots, thus spreading the risk of crop failure. In the upland rice fields, women depend on men for land access and to do the clearing of the bush for them. Widows, or women whose husbands are incapacitated, may need to opt for upland fields with low soil fertility because they can be cultivated with less effort per unit area. In the western part of the country land has become increasingly scarce and male strangers (farmers who settled in a village recently) may also have problems in terms of access to land, ending up with fields with low soil fertility.

These land tenure complexities, and their links to labor demands, characterise most West Africa farming systems but are quite complex in The Gambia because of its diverse production environments. In addition, rice and millet have different growth characteristics and thus labor requirements. It is important to note, however, that there is no relationship between the inputs used in rice and millet, when compared at compound level (Nuijten 2005). In other words, the two crops are produced independent of one another. Women and men living in the same compound largely work independently as economic actors. If in a particular compound men use fertiliser in millet, it is no guarantee that the women of the compound will have access to it, and vice versa. The same is true for the use of sowing machines. The upper stretches of the transitional zone from lowland to upland, where few trees grow, are well suited for mechanical sowing of rice; whereas in the inundated lowland fields, rice is transplanted by hand. In the true upland environment, broadcasting seed by hand is the only option because of tree stumps and other constraints. In all of these three environments, men are very reluctant to help their wives, or to lend them their sowing machines and donkeys. This indicates that rice and millet cultivation are two separate, rather independent production systems, even within the same family compound. It seems that men and women are quite comfortable in keeping it this way. Possibly, all of them know, as Jane Guyer argued, that technological innovation can lead to attempts by different groups within a community to exert control over production processes. This might also explain why women are also reluctant to learn to work with animals (e.g. donkeys) and machines (see Baker 1995), and why women are reluctant to harvest rice with a sickle instead of a small knife, which is viewed as a tool suitable for men but not for women. A more practical reason why women are reluctant to 
use donkeys may be that they cannot make much use of them in the rest of the year, unlike men who use donkeys outside the rainy season for carrying loads.

\section{Crop and variety portfolios of men and women}

Another gender difference is that in areas where women mainly grow rice, other crops grown by women are far less significant. Men, on the other hand, grow a portfolio of crops of more or less equal importance: millet, groundnuts or cassava, maize, and some other minor crops. Whereas women grow about 1.5 types of crops on average, the average man grows 4-5 (Table 2). In those areas where rice cultivation is not possible anymore, women grow the same crops as men, and, just like men, usually grow just one variety of each. In these areas no clear differences exist between the genders. In other countries where men are actively engaged in rice farming, like Sierra Leone, farmers use more varieties of rice than of other crops (Richards 1986). All this suggests therefore the high number of rice varieties is not because women grow rice, but rather that a high number of varieties are typical in the rice production system.

The wider spread of crops grown by men can also be attributed to the larger male labor force (the average dabadaa size is 5.1), when compared to the female labor force (the average sinkiroo size is 2.9). The number of crops per person is greater for men than for women. There is a positive association between labor availability and the number of crops grown by men (correlation $=0.285, \mathrm{p}=0,002 ; \mathrm{N}=120$ ) but not for labor availability on crops grown by women. Instead, there is a small significant relation between labor availability and number of rice varieties grown by women (correlation $=0.193 ; \mathrm{p}=0.027 ; \mathrm{N}=131$ ). In fact, it seems likely that the smaller number of crops grown per woman compared to men is compensated by the rice varieties grown by women. When adding the number of crops and number of rice varieties (3.2 per sinkiroo, Table 2) together, an average of 1.7 crops and rice varieties per member of the female workforce (sinkiroo) is obtained, which is higher than the average of 1.2 crops per member of the male workforce (dabadaa). Unfortunately, male farmers were not asked how many varieties of groundnuts, cassava and other crops they grow, so an unambiguous comparison is not possible, but from fieldwork it is clear that usually farmers grow one variety, and sometimes two varieties, of each of these crops. These figures suggest that there is a positive relationship between work force size and number of crops and varieties cultivated, which is unrelated to gender.

\begin{tabular}{l|cc|c|c|c|c}
\hline District & Number of crops & $\begin{array}{l}\text { Number of fruit } \\
\text { tree species }\end{array}$ & $\begin{array}{l}\text { \% women doing } \\
\text { gardening }\end{array}$ & $\begin{array}{l}\text { Number of rice } \\
\text { varieties cultivated by } \\
\text { women }\end{array}$ \\
\hline gender & 0 & + & 0 & + & & \\
\hline Kombo & 4.2 & 1.4 & 2.4 & 0.6 & 90 & 3.6 \\
Foni & 5.6 & 1.5 & 2.1 & 0.4 & 40 & 2.8 \\
Kiang & 3.7 & 1.2 & 0.8 & 0.1 & 40 & 2.8 \\
Fuladu & 5.5 & 2.0 & 1.3 & 0.6 & 80 & 3.2 \\
Total & 4.7 & 1.5 & 1.9 & 0.5 & 70 & 2.3 \\
\hline
\end{tabular}

Table 2: Average number of crops and fruit trees grown by men and women, and average number of rice varieties cultivated by women, shown per district; $\mathrm{N}=127$ for men and $\mathrm{N}=132$ for women.

\section{Variety management}

The breeding system of rice and millet is one of the main reasons more varieties exist for rice than millet (Nuijten and Almekinders 2008). Because rice is a self-pollinating crop, a rice variety reproduces the same characteristics every year, even if it is grown mixed with different varieties in the same field. Millet varieties, on the other hand, grown in the same field will merge into a single intermediate variety because of the cross-pollinating nature of millet allowing plants to exchange their genetic material. Hence, farmers can more easily maintain a large number of rice varieties than millet varieties. Furthermore, because of ecological complexity and food quality requirements, women need to maintain a wide range of rice varieties.

Another reason why women have a large portfolio of rice varieties is that through marriages outside their villages they have greater access to new rice varieties than men have to millet varieties. ${ }^{7}$ It is difficult, however, to assess how much this determines a difference between men and women in terms of variety management, because it can also be argued that men simply do not look for new millet varieties given the smaller number available and the nature of the crop.

\footnotetext{
${ }^{7}$ When women marry they move to the village of their husband. In that way an extensive seed network is created based on relatives living in different villages.
} 
Farmers' naming of millet varieties seems less consistent than for rice. It may be that men simply do not need to fuss about the consistency of names because the total number of millet varieties they need to distinguish is rather small. In addition, the development and introduction of new millet varieties, despite the work of crop breeding labs like ICRISAT on short cycle and disease resistant genotypes, is very low (Nuijten and Almekinders 2008). The difference in naming can largely be explained by the difference in breeding system, which in turn is related to the rate of introduction of new varieties. A low cross-pollination rate results in more new varieties. In the case of self-pollinating crops (like rice and beans), but also sorghum, new varieties are more easily developed and maintained from off-types (Nuijten and Almekinders 2008). When a newly introduced rice variety in a village is rapidly distributed among farmers, the variety obtains a specific name known by all farmers. In the cases that newly introduced varieties are not adopted by other farmers, the names are only known by the farmer who introduced them. Women generally have access to many varieties in rice and often use specific names for specific varieties. In contrast, men often add references to different plant characteristics onto the variety names, which suggest the existence of many different millet varieties. This is not really a problem when asking for seed from other male farmers because most male farmers within the same village grow the same variety of millet.

\section{Selection of seed.}

Gender does not seem to be a factor in how varieties are selected. There is no clear evidence that selection practices of men and women within the same compound are distinct (Nuijten, 2005). For millet and rice, respectively, most men and women select their seed during harvesting and the selection criteria they use are similar (big seeds, big panicle, well-filled panicle, absence of diseases). Moreover, men and women agreed that selection for rice and millet is the same and that they would look for the same desired traits.

The observed differences in seed selection between rice and late millet are related to plant structure. Since late millet is very tall, it needs. to be pushed down to the ground (making a tangle of stems, leaves and spikes) in order to cut the spikes; for certain late maturing varieties selection can take place only after removal of the bristles. Theoretically, because of the shorter height and absence of bristles in short cycle millet, selection may be done in the field before the main harvest, as is possible for rice. So, selection methods differ more between the various types of early and late millet, than between rice and millet. Hence, it seems clear that any differences in seed selection methods are related to differences in the plant morphology of rice and millet.

It seemed logical, at first sight, that women belonging to smaller sinkiroo, that need to do compound work as well as farm work, will lack time to do proper seed selection. However, no significant relationships were found. This shows the importance of seed selection in Gambian rural communities. Although there is no clear relationship between age and selection practices, there is a tendency, for both men and women, for older people to do seed selection at a later stage; people who set aside seed after threshing tend to be older people. Both men and women may vary their seed selection practices if needed, for example, in case of illness. They may wish to practice careful selection, but if short of labor, they may choose to do it only just before the new growing season starts, essentially using whatever grain is left for seed.

Men sometimes plant millet seedlings they get from other farmers instead of using their own sowing seed. The explanation by men is that all millet is very much the same. This could be interpreted as a lack of interest of men in the quality of millet seed. Genetic analysis, however, confirms millet seed just don't differ much (Nuijten and van Treuren 2007). Rice, being harvested panicle by panicle, theoretically allows for careful selection of the best panicles and of mixtures. But large numbers of panicles are needed for sowing seed, and women only reject diseased panicles and mixed-in varieties they really do not want. Observing women during harvesting, and seeing the mixed-in varieties remaining in the bundles meant for sowing, does not give the impression of women as careful selectors. However, once and a while women select interesting off-types during harvesting. Although it is difficult to find proper indicators, from informal interviews it became clear that some farmers have a greater personal interest in testing different varieties and selection methods than other farmers, as Prain (1994) also suggests. The personal interest of farmers could well have a bigger impact on farmer seed management and seed selection than any other well defined social factors.

\section{Selection of off-types}

For both millet and rice, a similar percentage (70\%) of men and women said they observe off-types in their fields (Nuijten, 2005). For both millet and rice, there are no differences here between ethnicities and across districts. For millet, there are also no differences between ecological zones. But for rice, all women who broadcast and transplant rice said they see off-types in their field. This is probably due to the fact that they handle more varieties and that early and late maturing varieties get mixed up and, consequently, are noticed quicker because of differences in flowering. The rather high percentage of male farmers observing off-types in millet is because some men said the off-types they find in their fields are mix-ins of short cycle millet, or sorghum accidentally occurring in late millet. The reason farmers consider sorghum and millet to be related can be clarified by reference to farmers' nomenclature for millet and sorghum (both being considered nyo, even although sorghum is called kinto). Some said they never see any off-types in their field, because in the wider area only one variety is grown. 
The occurrences of off-types are explained similarly by men and women but with slightly different emphases. A majority of women think that off-types in rice are caused by run-off water, followed by mixups during storage or threshing. A few women blamed God, birds, animals, the devil, and improper selection. The most common explanations given by men for the occurrence of off-types in millet are their seed mixtures, ants, birds, God, and run-off water. Less common explanations are: disease, improper selection, continuous cultivation in the same field, and low soil fertility. Some women and men said they do not have any idea. After sowing, it is very common for ants and birds to carry the seeds away. These explanations are related to recurrent events in millet and rice fields. That women did not mention ants, which are not very common in lowland fields, whereas men did, and that more women mentioned run-off water typical for lowland rice cultivation, suggests that the somewhat different answers by women and men can be best explained by differences in ecological conditions, agronomic practices and plant characteristics.

\section{Farmers' perceptions of strange off-types}

'Strange off-types' are plants that cannot be classified as mix-ins, or as O. glaberrima (in the case of rice) or early/short cycle millet (in the case of millet). These strange varieties are either unfamiliar existing varieties or 'new' off-types resulting from cross-pollination.

When women are asked whether they see any strange off-types in their fields, most said they only see mix-ins (other common varieties that got mixed up) in their field, but some women said they observe both mix-ins and strange off-types. Most say they are caused by God or Nature. A few women mentioned heavy rain. Most women said they would thresh and eat strange off-types. Fewer said they would test them in the next season (Nuijten, 2005). Reasons women consume these strange off-types instead of testing them is that they do not fit the local ecology, don't look impressive, or because they lack time or 'patience'. ${ }^{8}$

When asking men whether they see any strange off-types (unusual varieties never seen before) in their millet, their first response is often "Yes, it is possible to see mix-ins" or "If you sow sorghum, you harvest sorghum, if you sow millet, you harvest millet". Another common similar response is "Sanyo (late millet) gives sanyo, suno (early millet) gives suno". In other words, many men said they never saw any strange offtypes in millet. After more probing, a few men said they have seen some unusual millet plants. None of those farmers said they tested them. A few farmers attributed the strange off-types they saw to diseases or soil fertility. Other men said that these have a natural cause. In Tujereng, "AJ" said that there are sometimes plants with red seeds growing in his field. He had never used them for sowing seed and never tested them, since he has no idea what conditions they need. He does know the conditions his own variety needs either, and would eat the red variety. Still, each year, there are some plants with red seeds, origin unknown. "OJ" said there are plants with shorter or longer spikes, which have fewer bristles. He does not know why, but he knows that cassava also changes, so it may be natural. "FS" put it this way: "There are always plants that look different, even if you do the selection very well: This difference has a natural cause - your children also look different."

"KM" said he has seen spikes with red seeds, but he does not discard them, because it is still millet. He has never seen any strange sorghum plants. He does not know why rice rather than sorghum and millet throw up strange varieties. One man in Sangajor identified the same issue - he does not know why rice has strange off-types, but it happens. "MJ" said that if you sow white millet, black millet sometimes comes out of it, and that also the reverse is true; if you sow black millet, some white millet results. He also said that this was the origin of the rice variety Binta Sambou: it was found in a field of Kari Saba; and Binta Sambou and Kari Saba look alike. He knows that red millet appears in his field every year. Some people, long ago, separated a small bundle of red millet, which eventually they gave to women to be threshed, pounded, and made into munkoo ${ }^{9}$, which tasted very nice. He once separated red millet intending to sow it, but eventually decided not to. He gave no particular reason for this change of mind. He suggested that the reason no man has ever found a new variety of millet is that men do not have their mind on that, whereas women are keenly interested:

For sorghum, it also happens that men see new varieties emerging in the field. If the field is big, you must see several strange plants. These are caused by God. Even if you select your seed carefully, to make sure that there are no off-types in your seed, you will still find different plants in the field.

He has never heard of men selecting strange sorghum plants for sowing. "AJ-2" also sometimes sees spikes with dark brown seeds, which he harvests together with the rest of the field. He does not keep them apart and does not test them. He said he has never heard of men selecting a new variety of millet. Men never did that, finding new varieties is something done by women. Women are naturally more curious than men, he believes. A different explanation was given by "MJ-2", supported by a few other men. "MJ-2" claimed

\footnotetext{
${ }^{8}$ Some women who said they would test any strange varieties said they had, in fact, never seen any, although they knew they could occur. One woman in Tujereng, aged 50, said the first year she found a strange variety was 2000.

${ }^{9}$ Dough made of either millet or rice flour and water.
} 
that men never selected any new variety of millet or sorghum because they are too busy in the field and lack time to harvest strange plants separately, whereas women have more time to harvest strange plants separately. This seems an odd comment, given that, in general, women are far busier. What is different is the process of harvesting. A millet field is harvested by a few older men and many boys who harvest a field in a couple of days, while a rice field is harvested by a few women a piece at a time and they may take a couple of weeks to complete the work. Usually, boys (or youths) are inexperienced in farming, and have little eye for differentiating off-types.

The only off-type in millet described by men is the red seeded variety. For millet, clearly distinctive off-types are infrequent occurrences in the field because of its outbreeding nature and variation within seed lots (Nuijten 2005). Because of the wide variation among plants, an off-type will not be easily considered distinctive.

\section{A grouping exercise}

Very early during fieldwork some male and female farmers made interesting comments in replying to questions about variety management. Some men mentioned they do not understand how women can distinguish all those different rice varieties. Men often reinforce gender differences in conversation, arguing it is typical for women to differentiate so many rice varieties, and that men can't do it. Men would often say that millet is millet and that there are actually no real differences between plants, despite the obvious visible differences in plant height, spike size, bristle length, bristle colour, etc. Women would sometimes say that men lack interest in variety management and do not bother about millet varieties. When visiting women's rice fields, women will explain the characteristics of the many rice varieties and why a particular plant belongs to this variety and not to another.

Because of the specific features of the Gambian farming system, women are known as much more careful selectors than men. A small grouping exercise was set-up to test whether women are actually better in distinguishing varieties by nature. It was assumed that, since men actually do the work in the millet field and women in the rice field, men would be more accurate in grouping millet and women in grouping rice. ${ }^{10}$ First the results of the grouping of millet spikes are presented, followed by the results of the grouping of rice panicles.

Millet

Most people - both men and women - made two groups for millet, often calling them black and white millet. Some made three groups and a few made four groups (Table 3). From earlier interviews it appeared farmers in Faraba think there are more millet varieties than in Tujereng, but this does not clearly show in the results of this exercise.

\begin{tabular}{c|ccc|ccc}
\hline & Men & & & Women & & \\
\# groups & Faraba & Tujereng & All men & Faraba & Tujereng & All women \\
\hline 2 & 5 & 6 & 11 & 6 & 7 & 13 \\
3 & 4 & 4 & 8 & 3 & 4 & 7 \\
4 & 1 & 1 & 2 & 1 & 0 & 1 \\
Average & 2.6 & 2.5 & 2.6 & 2.5 & 2.4 & 2.4 \\
\hline
\end{tabular}

Table 3: Number of groups that were made with the millet spikes by men and women from Faraba and Tujereng ( $\mathrm{N}=10$ for Faraba and $\mathrm{N}=11$ for Tujereng, for men and women).

After grouping, the farmers were asked to describe or name their grouping. In total 14 different groups were identified, 7 groups by both men and women, 4 by men only, and 3 by women only. Nine groups were named or described by the colour of their seeds, three groups were named according to variety type, and one group was described by seed size. There were no clear differences in how men and women named or described the groups. The two most common groups were white and black. These accounted for $79 \%$ of all the spikes assigned to a group. Five groups were identified in Tujereng only and four groups were identified in Faraba only. The groupings made by men and women were more consistent with each other within each village than were the groupings made by men from Faraba and Tujereng, and the women from Tujereng and Faraba. This suggests that within each village there is a somewhat specific discourse on millet, not only among men of the same village, but also between men and women of the same village.

Further, the number of men and women allocating each spike to a specific group was analysed. If less than three men or women allocated the spike to a different group than the main group, it is considered as a

${ }^{10}$ During the grouping men complained that we should not ask them to group rice panicles, and women likewise complained they did not know anything about millet and therefore claimed they could not group the millet spikes. 
very consistent grouping. If less than four men or women had allocated the spike to a different group, this is considered as a consistent grouping. Table 4 shows the number of millet spikes for which men and women from Faraba and Tujereng produced very consistent or consistent groupings. The results show that in Tujereng the grouping was more consistent than in Faraba, and that women produced more consistent groupings than men.

The difference in grouping consistency between the two villages is largely explained by the fact that in Tujereng fewer strangers were asked to participate compared to Faraba. The village of Faraba as a whole has more strangers than Tujereng. Hence, village discourse in Faraba on millet varieties is more diverse, because strangers come from various regions and have experience with more and different varieties.

The reason women do a more consistent grouping than men is probably because they did the grouping based on qualitative traits, mainly seed colour, whereas men also considered the size of the spikes. For example, two extremely big, impressive spikes with mixed seed colour (both black and white) were classified by most men as black, whereas $50 \%$ of the women classified them as white, and $50 \%$ as black (in both villages men prefer to grow black millet). Earlier observations also showed that some men from Tujereng would include impressive spikes with white seed in their seed stock of black millet.

\begin{tabular}{c|cc|cc}
\hline \multirow{2}{*}{ Village } & \multicolumn{2}{|c|}{ Number of spikes grouped by men } & \multicolumn{2}{|c}{ Number of spikes grouped by women } \\
\cline { 2 - 5 } & very consistent $^{1)}$ & consistent $^{2)}$ & very consistent & (1) $^{\text {consistent }}{ }^{2)}$ \\
\hline Faraba & 0 & 7 & 1 & 15 \\
Tujereng & 10 & 14 & 27 & 29 \\
All & 0 & 0 & 0 & 8 \\
\hline
\end{tabular}

Table 4: Number of millet spikes (out of 35) for which men and women from Faraba and Tujereng did a consistent or very consistent grouping $(\mathrm{N}=10$ for Faraba and $\mathrm{N}=11$ for Tujereng, for men and women).

1) $=$ number of spikes for which less than three people did inconsistent grouping

${ }^{2)}=$ number of spikes for which less than four people did inconsistent grouping

Rice

For rice, a similar exercise was conducted with 30 panicles of 15 O. sativa varieties, 2 O. glaberrima varieties and $4 \mathrm{O}$. sativa off-types. Varieties that do not shatter their seeds easily were used. For that reason more varieties cultivated in Tujereng were used than in Faraba. ${ }^{11}$ Table 5 shows that, for rice, both men and women make more groups than they do for millet and that the number of groups per informant varies a lot, from 4 up to 21 . Women make slightly more groups of rice than men (not significant with Student's t-test). There is no clear difference in the number of groups of rice panicles between Faraba and Tujereng.

\begin{tabular}{cccccc}
\hline & Village & $\begin{array}{c}\text { Average } \\
\text { number of } \\
\text { groups }\end{array}$ & $\begin{array}{c}\text { Std. } \\
\text { deviation }\end{array}$ & Minimum & Maximum \\
\hline Men & Faraba & 9.2 & 5.16 & 4 & 19 \\
& Tujereng & 10.2 & 4.94 & 5 & 18 \\
& total & 9.7 & 4.94 & 4 & 19 \\
\hline Women & Faraba & 12.1 & 5.32 & 4 & 20 \\
& Tujereng & 11.9 & 4.46 & 6 & 21 \\
& total & 12.0 & 4.76 & 4 & 21 \\
\hline \multirow{2}{*}{ Total } & Faraba & 10.7 & 5.31 & 4 & 20 \\
& Tujereng & 11.0 & 4.67 & 5 & 21 \\
& total & 10.9 & 4.93 & 4 & 21 \\
\hline
\end{tabular}

Table 5: Average number of groups of rice panicles made by men and women from Faraba and Tujereng ( $\mathrm{N}=10$ for Faraba and $\mathrm{N}=11$ for Tujereng, for men and women).

The analysis undertaken to understand the consistency of the millet grouping was not done for rice, since the grouping of rice panicles was far more diverse. Instead, I made a standard grouping of the varieties

\footnotetext{
${ }^{11}$ Non-shattering varieties were chosen to avoid people at the start of the experiment doing different groupings to those at the end, as the appearance of the panicles changed as more seeds are shaken loose in handling.
} 
based on their morphological similarities (each group thus containing several similar varieties) and the grouping of the farmers was compared to that baseline. Each variety corresponding to my grouping got one point, and the total number of points was added. This means that 30 points is the maximum score. The average, minimum and maximum scores are shown in Table 6. Overall, women got a higher score $(p=0.001$ with Student t-test) than men, but the differences were not significant when men and women of each village were compared. The scores for the people from Tujereng were slightly higher than those for the people from Faraba, which is because the people from Tujereng were more familiar with the rice material (more varieties suitable for testing - i.e. non shattering - came from Tujereng). This indicates that there is a learning aspect in differentiating rice varieties. Furthermore, the minimum and maximum scores indicate that there is huge variation in grouping capacities between individuals of both genders. Some men from Tujereng were almost as accurate in grouping as certain women.

\begin{tabular}{cccccc}
\hline & Village & $\begin{array}{c}\text { Average } \\
\text { score }\end{array}$ & $\begin{array}{c}\text { Std. } \\
\text { deviation }\end{array}$ & Minimum & Maximum \\
\hline \multirow{2}{*}{ Men } & Faraba & 14.3 & 2.31 & 10 & 17 \\
& Tujereng & 15.3 & 4.63 & 10 & 23 \\
& total & 14.8 & 3.66 & 10 & 23 \\
\hline \multirow{2}{*}{ Women } & Faraba & 17.1 & 2.81 & 12 & 20 \\
& Tujereng & 21.3 & 4.31 & 12 & 26 \\
& total & 19.3 & 4.17 & 12 & 26 \\
\hline \multirow{2}{*}{ Total } & Faraba & 15.7 & 2.89 & 10 & 20 \\
& Tujereng & 18.3 & 5.34 & 10 & 26 \\
& total & 17.0 & 4.49 & 10 & 26 \\
\hline
\end{tabular}

Table 6: Average scores men and women from Faraba and Tujereng got for grouping rice panicles $(\mathrm{N}=10$ for Faraba and $\mathrm{N}=11$ for Tujereng, for men and women).

\section{Discussion}

These findings have sought to illustrate clear gender differences in seed selection practices, and the related crop management of rice and millet in The Gambia. In general men were found to have more material resources than women in all the study villages. The nature of the differences observed in variety management of rice and millet suggest that they are the result of a complex interaction of various plant characteristics and socio-economic and agro-ecological factors. Crucial differences exist between rice and millet in terms of plant characteristics, the breeding system for these crops, and plant architecture. Of the socio-economic factors the most important differences between men and women are the nature of the crop portfolio, and labor organisation, supporting other studies. What may possibly make The Gambia different is that there is a clear interaction between plant characteristics and socio-economic factors which is less obvious in other case studies.

The results of the grouping experiment suggest women have a somewhat keener eye for differentiating varieties than men, but there is no categorical difference in the ability of men and women to recognise and differentiate crop varieties. Men and women differentiate similar numbers of groups with the millet spikes and rice panicles. Women group the millet spikes more uniformly than men, but the grouping of rice panicles shows that accuracy among women also varies considerably. The keener eye of women may, in fact, be age-related. The experiment was undertaken among married couples, which means that the men, on average, were considerably older than the women and eye sight deteriorates with age. Another explanation is that women need to differentiate rice varieties continuously (it is need in rice farming), and thus school themselves in differentiating varieties, whereas there is less need for men to acquire these skills for millet.

The millet grouping exercise suggests that women made their choices based on panicle appearance, while men used morphological information. This distinction did not show up in the rice grouping, which might be because the diversity in rice panicles is not continuous, whereas variation in millet spikes tends to be more so. This means that a rice variety can be more clearly defined by its traits and therefore is more generally recognised, whereas the definition of a millet variety is less clear and thus less readily recognised as a discrete variety. Thus, working with different crops in which variety presents itself differently, may lead to different didactic outcomes. The grouping exercise also showed that group dynamics and social learning play a role in selection practices. Men and women of the same village did the grouping of millet in a similar way, while the groupings showed (small) differences between the two villages. These findings confirm that differences in variety and seed management are determined by socio-cultural, plant-related and agronomic factors and their interactions.

Perhaps the most important conclusion to be drawn from the grouping experiment is that, whereas men suggested that they cannot differentiate rice varieties as well as women, in reality there is no clear difference 
between the genders. This suggests that claiming or denying capacities in relation to varietal differentiation (and other activities) is more part of gender identity than something based on actual skill. Rather, it may be argued that seed selection is a "feminine trait" that is actually shared by both women and men (see Mestrovic 1992; Shiva 1988).

One question that remains unanswered in this analysis is whether previously, before a clear genderbased division of labor developed, women harvested and selected seed in millet (Carney 1993; Swindell 1992; Watts 1993). This could help explain why women seem more eager and knowledgeable in experimenting with seed and varieties than men - i.e. they have a culture of experimentation with seeds based on an historical division of labor. Another question is whether the commercialisation of groundnuts pushed women into a more disadvantaged position, and whether before this, women had a more independent position in society with less male control. Gender roles are not static and change over time depending on the dynamics of socio-economic, cultural and agro-ecological factors. Several researchers have suggested that women gained some economic independence in the 1950s by increasing their rice production (Haswell, 1975, Webb, 1992). With the increased significance of vegetable gardening since the 1970s, some women are gaining yet more economic independence. Women's sphere of influence must fluctuate over time: it decreased with the commercialisation of groundnuts in the $19^{\text {th }}$ century, and is now increasing with the increased importance of vegetable gardening.

\section{Conclusions and broader implications}

We should be cautious about general claims that seed selection and variety management reside primarily with women, at least in the region researched for this paper. We should be aware that positive capacities attributed to a particular gender may actually be the result of social mechanisms of exclusion; there is a political ecology to gendered seed selection. If we want to improve agriculture it is not enough to identify seemingly positive aspects of farming systems on which to build. We also need to ascertain whether these aspects may be the result of social processes that leave women in a disadvantaged position from which it is hard to access adequate resources or to improve their situation. So, instead of searching for evidence that women are naturally good in seed selection and maintenance (see Howard 2003; Shiva 1988), research should look for ways to change the socio-political frameworks in which women usually deal with laborintensive farming and are put in disadvantaged positions, while men deal with the cash crops and have a range of technologies at their disposal. Guyer (1984) noted that with the introduction of agricultural technologies, social relationships are often reshaped to exert control over the production process. Today the question is how to reshape these relationships to the advantage of disadvantaged social groups, in this case women but also youth.

Agricultural development projects in The Gambia that had agricultural improvement and poverty alleviation as an aim have focused on the distribution of new technologies, such as irrigation and dams, improved crop varieties, fertilisers, ploughs and row seeders. There has been little attention given by development agencies to the interactions between technologies and the socio-economic and ecological environments they reside in (Carney, 1993; 1998). For each farming system, more specific questions should be asked about who is responsible for which activities and how specific tasks are carried out. For example, in the context of crop development it is not sufficient to know who is responsible for variety management, because we also need to understand how labor is organised for a task such as harvesting, and how it shapes local seed selection practices. This implies that for participatory crop (or technology) development to be successful, researchers should try at length to understand why certain people are responsible for certain tasks in a particular farming system, and how these tasks are embedded in the local social framework. These questions are equally important for understanding the local development of agricultural technologies in general.

The grouping experiment described in this paper was specifically targeted towards understanding gender differences. Social factors, such as age and social class could also be studied in a similar way, even if they are les clear-cut categories. In respect to the relationship between crop diversity and social class, contradicting conclusions have been reported elsewhere, some linking richer individuals to better crop diversity management; others just the opposite. Further experiments and qualitative studies may help understand why these contradictions occur, and reveal the real mechanisms explaining the relationship between societal groups and crop diversity management practices.

\section{References}

Baker, K.M. 1995. Drought, agriculture and environment: a case study from The Gambia, West Africa. African Affairs 94: 67-86.

Barrett, H.R. 1988. The marketing of foodstuffs in The Gambia, 1400-1980. Aldershot: Avebury.

Boserup, E. 1970. Woman's role in economic development. New York: St. Martin's Press.

Brooks, G.E. 1993. Landlords and strangers: ecology, society and trade in Western Africa, 1000-1630. Oxford: Westview Press. 
Gender and management of crop diversity in The Gambia

Carney, J.A. 1989. The social history of Gambian rice production: an analysis of food security strategies. $\mathrm{PhD}$ dissertation, Dept. of Geography, University of California, Berkeley. $351 \mathrm{p}$.

Carney, J.A. 1992. Peasant women and economic transformation in The Gambia. Development and Change 23(2): 67-90.

Carney, J.A. 1993. Converting the wetlands, engendering the environment: the intersection of gender with agrarian change in The Gambia. Economic Geography 69(4): 329-348.

Carney, J.A. 1998. Women's land rights in Gambian irrigated schemes: constraints and opportunities. Agriculture and Human Values 15: 325-336.

Guyer, J.I. 1980. Food, cocoa and the division of labor by sex in two West African societies. Comparative Studies in Society and History 22(3): 355-373.

Guyer, J.I. 1984. Naturalism in models of African production. Man 19: 371-388.

Haswell, M.R. 1963. The changing pattern of economic activity in a Gambian village. Overseas Research Publication 109. London, Department of Technical Co-operation.

Haswell, M.R. 1975. The nature of poverty: a case history of the first quarter-century after World War 2. London, MacMillan

Haswell, M.R. 1991. Population and change in a Gambian rural community, 1947-1987. In Rural households in emerging societies: technology and change in sub-Saharan Africa, 141-172 (Eds.. M.R. Haswell and D. Hunt). Oxford: Berg Publishers.

Howard, P.L. 2003. Women and the plant world: an exploration. In Women and plants: gender relationships in biodiversity management and conservation, 1-48 (Ed. P.L. Howard). London: Zed.

Johnny, M., Karimu, J. and P. Richards 1981. Upland and swamp rice farming systems in Sierra Leone: the social context of technological change. Africa 51(2): 596-620.

Jusu, M. S. 1999. Management of genetic variability in rice (Oryza sativa L. and O. glaberrima Steud.) by breeders and farmers in Sierra Leone. PhD dissertation. Wageningen: Wageningen University.

Kea, P. 2004. Maintaining difference and managing change: Female agrarian clientelist relations in a Gambian community. Africa 74: 361-382.

Lewis, J.V.D. 1981. Domestic labor intensity and the incorporation of Malian peasant farmers into localized descent groups. American Ethnologist 8: 53-73.

Linares, O. 1981. From tidal to inland valley: On the social organization of wet rice cultivation among the Diola of Senegal. Africa 51(2): 557-595.

Linares, O. 1992. Power, prayer \& production: the Jola of Casamance. New York: Cambridge Publishers.

Marong, A.J., Chen, Y.S., Jallow, E.S., Senghore, A., Jallow, B.G., Faal-Njie, M. and D. N'Dow 2001. Towards self-sufficiency: Strategies for enhancing sustainable rice development in The Gambia. Department of State for Agriculture.

Mestrovic, S.G. 1992. Durkheim and postmodern culture. New York: Aldine de Gruyter.

Moore, H.L. 1988. omenGender and status: explaining the position of w. In Feminism and anthropology, 12-41 (Ed H.L. Moore). Cambridge: Polity Press.

Nuijten, E. 2005. Farmer management of gene flow: The impact of gender and breeding system on genetic diversity and crop improvement in The Gambia. PhD Thesis, Wageningen University, Wageningen, The Netherlands.

Nuijten, E. and R. Van Treuren 2007. Spatial and temporal dynamics in genetic diversity in upland rice and late millet in The Gambia. Genetic Resources and Crop Evolution 54, 989-1009.

Nuijten, E. and C.J.M. Almekinders 2008. Mechanisms explaining variety naming by farmers and name consistency of rice varieties in The Gambia. Economic Botany 62(2) 148-160.

Nyanteng, V.K., Samake, M. and Longabough, S. 1986. Socio-economic study of rice farming in Mali: the household, farm labor characteristics and constraints. Monrovia: West Africa Rice Development Association.

Prain, G.D. 1993. Mobilizing local expertise in plant genetic resources research. In Cultivating knowledge: genetic diversity, farmer experimentation and crop research, 102-110 (Eds.. W. de Boef, K. Amanor and K. Wellard). London: Intermediate Technology Publications. 
Gender and management of crop diversity in The Gambia

Prain, G.D. 1994. Local knowledge and global science: the need for partnership in plant genetic resources research. In Local knowledge, global science and plant genetic resources: towards a partnership: proceedings of an international workshop on user participation in plant genetic resources research and development, May 4 - 8, 1992, Maxine Hotel, Alaminos, Pangasinan, 1-10 (Eds.. G.D. Prain and C.P. Bagalanon). Los Banos: UPWARD.

Rice, E., Smale, M. and Blanco, J-L. 1998. Farmers' use of improved seed selection practices in Mexican maize: Evidence and issues from the Sierra de Santa Marta. World Development 26(9): 1625-1640.

Richards, P. 1986. Coping with hunger: hazard and experiment in an African rice-farming system. London: Allen \& Unwin.

Salick, J., Cellinese, N. and S. Knapp 1997. Indigenous diversity of cassava: generation, maintenance, use and loss among the Amuesha, Peruvian Upper Amazon. Economic Botany 51(1): 6-19.

Schroeder, R.A. 1997. Shady practices: agroforestry and gender politics in The Gambia. Berkeley: University of California Press.

Shiva, V. 1988. Staying alive: women, ecology and development. London: Zed Books Ltd.

Shiva, V. and I. Dankelman 1992. Women and biological diversity: lessons from the Indian Himalaya. In Growing diversity: genetic resources and local food security, 44-50 (Eds.. D. Cooper, R. Vellve and H. Hobbelink). London: Intermediate Technology Publications.

Song, Y. and J. Jiggins 2003. Women and maize breeding: The development of new seed systems in a marginal area of South-west China. In Women \& Plants: Gender relations in biodiversity management and conservation, 273-288 (Ed. P.L. Howard). London: Zed Books.

Sperling, L., Loevinsohn, M. E. and B. Ntabomvura 1993. Rethinking the farmers role in plant breeding: local bean experts and on-station selection in Rwanda. Experimental Agriculture 29(4): 509-519.

Swindell, K. 1980. Serawoollies, Tillibunkas and strange farmers: the development of migrant groundnut farming along the Gambia River, 1848-95. Journal of African History 21: 93-104.

Swindell, K. 1992. African food imports and agricultural development: peanut basins and rice bowls in The Gambia, 1848-1933. In Agricultural change, environment and economy: essays in honour of W.B. Morgan, 159-179 (Eds.. K. Hoggart and W. B. Morgan). London: Mansell.

The annual report of the Department of Agriculture for the year 1924. 1925 Colony of the Gambia. London, Crown agents for the colonies.

The annual report of the Department of Agriculture for the year 1925. 1926 Colony of the Gambia. London Crown agents for the colonies.

The annual report of the Department of Agriculture for the year ended March $31^{\text {st }}, 1931$. 1931 Colony of the Gambia. London, Crown agents for the colonies.

The annual report of the Department of Agriculture for the year ended March $31^{\text {st }}$, 1932. 1932 Colony of the Gambia. Bathurst, Government printer

The report of the Department of Agriculture for the period $1^{\text {st }}$ April, 1933 to $31^{\text {st }}$ May, 1934. 1934 Colony of the Gambia. Bathurst, Government printer

The report of the Department of Agriculture for the period ending 31 ${ }^{\text {st }}$ May, 1935. 1935 Colony of the Gambia. Bathurst, Government printer

The report of the Department of Agriculture for the period ending 31 $1^{\text {st }}$ May, 1936. 1936 Colony of the Gambia. Bathurst, Government printer

The report of the Department of Agriculture for the period ending $31^{\text {st }}$ May, 1939. 1939 Colony of the Gambia. Bathurst, Government printer

Tosh, J. 1980. The cash-crop revolution in tropical Africa: an agricultural reappraisal. African Affairs 79: 7994.

Toulmin, C. 1992. Cattle, women and wells: managing household survival in the Sahel. Oxford: Clarendon Press.

Van Oosterhout, S. 1996. What does in situ conservation mean in the life of a small-scale farmer? Examples from Zimbabwe's communal areas. In Using diversity: enhancing and maintaining genetic resources on-farm: proceedings of a workshop, held on 19 - 21 June 1995, New Dehli, India, 35-51 (Eds.. L. Sperling and M.E. Loevinsohn). New Delhi: International Development Research Centre, Regional Office for South Asia.

Watts, M.J. 1993. Idioms of land and labor: Producing politics and rice in Senegambia. In Land in African Agrarian Systems, 157-193 (Eds.. T.J.Bassett and D.E. Crummey). 
Webb, J.L.A. 1992. Ecological and economic change along the middle reaches of the Gambia river, 19451985. African Affairs 91: 543-565.

Weil, P.M. 1970. The introduction of the ox plow in central Gambia. In African food production systems: cases and theory, 229-263 (Ed. McLoughlin P.F.M.). Baltimore: Johns Hopkins Press.

Weil, P.M. 1973. Wet rice, women, and adaptation in The Gambia. Rural Africana 19: 20-29.

Weil, P.M. 1984. Slavery, groundnuts, and the European capitalism in the Wuli kingdom of Senegambia, 1820-1930. Research in Economic Anthropology 6: 77-119.

Whitehead, A. 1984. 'I'm hungry, mum' The politics of domestic budgeting. In Of marriage and the market: women's subordination internationally and its lessons, 93-116 (Eds.. K. Young, C. Wolkowitz and R. MacCullagh). London: Routledge and Kegan Paul.

Worede, M. and H. Mekbib 1993. Linking genetic resource conservation to farmers in Ethiopia. In Cultivating knowledge: genetic diversity, farmer experimentation and crop research, 78-84 (Eds.. W. De Boef, K. Amanor and K. Wellard). London: Intermediate Technology Publications.

Zimmerer, K.S. 1991. Labor shortages and crop diversity in the southern Peruvian Sierra. Geographical Review 81(4): 414-432.

\begin{abstract}
It is sometimes argued that women play a more important role in seed and diversity management than men, and that women have greater abilities in managing crop diversity. In The Gambia, men and women also have the belief that women are better in managing and identifying varieties than men. This article focuses on the role of gender in farmer management of crop diversity in two crops, rice which is cultivated by women and pearl millet which is cultivated by men. First a historical overview is given of the role of gender in farming. The management of crop diversity in rice and millet and gendered knowledge in The Gambia is described in detail. Lastly, a grouping experiment with rice panicles and millet spikes is described. The article shows that clear differences exist between the farming practices of men and women, and these are based on a complex interplay of socio-economic and agro-ecological factors. But the differences in seed selection practices of men and women are small, and those differences that exist can best be explained by a complex of agroecological factors and rice and millet characteristics. The grouping experiment showed no significant differences in the way men and women grouped rice panicles and millet spikes. Together these findings suggest that the supposedly better skills of women in crop variety management are related to their gender identity rather than to any biological differences. Instead of taking the supposedly strong skills of women in seed and variety management as a starting point for agricultural development, it is better to understand the underlying mechanism that keep women in disadvantaged positions in rural societies and to try to change these mechanisms for their benefit.
\end{abstract}

Key words: The Gambia, gender, agricultural labor, crop variety management

\title{
Résumé
}

Il est parfois affirmé que les femmes jouent un rôle plus important dans la gestion de la diversité des semences que les hommes, et que les femmes ont une plus grande affinité dans la gestion de la diversité des cultures. En Gambie, les hommes ont aussi la croyance que les femmes sont mieux dans la gestion et l'identification des variétés que les hommes. Cet article se concentre sur le rôle du genre dans la gestion paysanne de la diversité des cultures dans deux cultures, le riz qui est cultivé par les femmes et le mil qui est cultivé par des hommes. D'abord un apercu historique est donnée du rôle des femmes dans l'agriculture. La gestion de la diversité des cultures de riz et de mil est décrite. Enfin, une expérience de regroupement à panicules de riz et les pointes de mil est décrite. L'article montre que des différences notables existent entre les pratiques agricoles des hommes et des femmes. et celles-ci sont basées sur une interaction complexe de facteurs socio-économiques et agro-écologiques. Mais les différences dans les pratiques de sélection des semences, des hommes et des femmes sont petite, et ces différences qui existent peuvent être mieux expliquée par un ensemble de facteurs agro-écologiques et les caractéristiques du riz et du mil. L'expérience de regroupement (grouping experiment) n'a montré aucune différence significative dans la façon dont les hommes et les femmes regroupées en panicules de riz et les pointes de mil. Ensemble, ces résultats suggèrent que les compétences prétendûment supérieure des femmes dans la gestion de la diversité des cultures sont liées à leur identité de genre plutôt qu'à des différences biologiques. Au lieu de prendre les compétences importantes des femmes comme point de départ pour le développement agricole, il est mieux de comprendre le mécanismes qui défavorisé les femmes en sociétés rurales et de tenter de modifier ces mécanismes à leur profit.

Mots clés: La Gambie, genre, main d'ouvre, gestion des variétés de cultures 


\section{Resumen}

A veces se argumenta que las mujeres desempeñan un papel más importante que los hombres en la gestión de la diversidad de semillas, y además, la mujer tiene mayor afinidad en la gestión de la diversidad de cultivos. En Gambia, hombres y mujeres también tienen la creencia de que las mujeres son mejores en la gestión e identificación de las variedades que los hombres. Este artículo se centra en el papel que tiene cada género como agricultor en la gestión de la diversidad de cultivos en dos cultivos en particular: el arroz que se cultiva por las mujeres y el mijo perla cultivada por los hombres. En primer lugar, se entrega una visión histórica del papel del género en la agricultura. La gestión de la diversidad de los cultivos de arroz y el mijo y el conocimiento de cada género en Gambia se describe en detalle. Por último, se describe un experimento de agrupación con panículas de espigas de arroz y el mijo. El artículo muestra que existen claras diferencias entre las prácticas agrícolas de los hombres y mujeres, y éstas se basan en una compleja interacción de factores socio-económicos y agro-ecológicas. Pero las diferencias en las prácticas de la selección de semillas de hombres y mujeres son pequeños, y las diferencias que existen pueden explicarse más que nada por un conjunto de factores agro-ecológicos y por las características del arroz y del mijo. El experimento de la agrupación no mostró diferencias significativas en la forma en que hombres y mujeres agrupan panículas de arroz y los picos de mijo. En conjunto, estos resultados sugieren que las supuestas mejores habilidades de las mujeres en el manejo de cultivos diversos se explican por su identidad de género y no por las diferencias biológicas. En lugar de tomar las supuestas fuertes habilidades de las mujeres en las semillas y la variedad de gestión como punto de partida para el desarrollo agrícola, es mejor comprender el mecanismo subyacente que mantiene a las mujeres en posicion de desventaja en las sociedades rurales y tratar de cambiar estos mecanismos para su beneficio.

Palabras clave: Gambia, el género, el trabajo, manejo de cultivos diversos 